\title{
Covid-19 Pandemic and Human Resource Management in Nigeria: The Realities
}

\section{Alonge, Opeyemi Mojisola}

To Link this Article: http://dx.doi.org/10.6007/IJARBSS/v11-i3/8948

DOI:10.6007/IJARBSS/v11-i3/8948

Received: 01 January 2021, Revised: 28 January 2021, Accepted: 17 February 2021

Published Online: 14 March 2021

In-Text Citation: (Alonge, 2020)

To Cite this Article: Alonge, O. M. (2020). Covid-19 Pandemic and Human Resource Management in Nigeria:

The Realities. International Journal of Academic Research in Business and Social Sciences, 10(14), 319-330.

\section{Copyright: (c) 2021 The Author(s)}

Published by Human Resource Management Academic Research Society (www.hrmars.com)

This article is published under the Creative Commons Attribution (CC BY 4.0) license. Anyone may reproduce, distribute, translate and create derivative works of this article (for both commercial and non-commercial purposes), subject to full attribution to the original publication and authors. The full terms of this license may be seen at: http://creativecommons.org/licences/by/4.0/legalcode

Full Terms \& Conditions of access and use can be found at http://hrmars.com/index.php/pages/detail/publication-ethics 


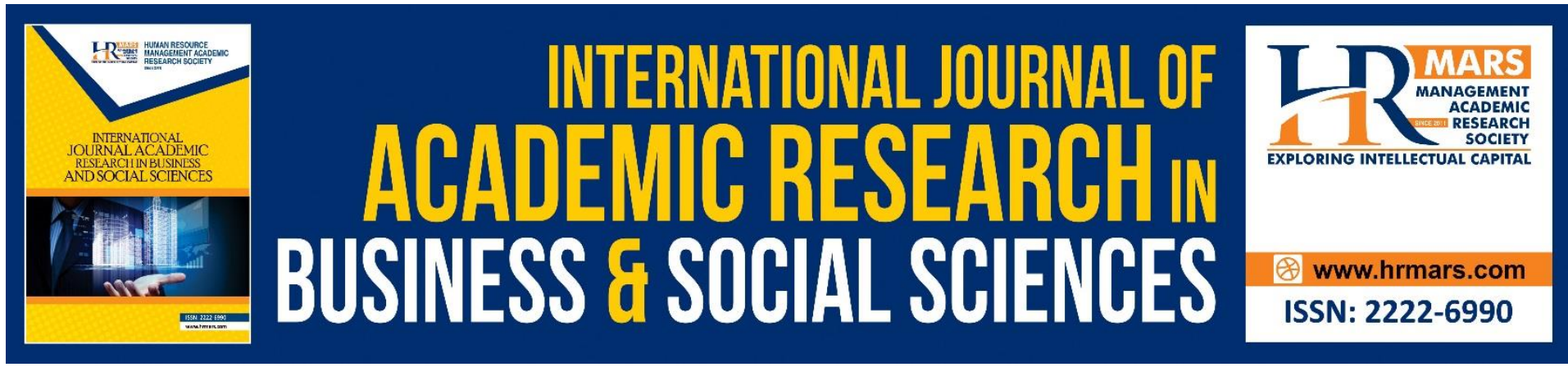

\title{
Covid-19 Pandemic and Human Resource Management in Nigeria: The Realities
}

\author{
Alonge, Opeyemi Mojisola \\ Department of Public Administration, Rufus Giwa Polytechnic, Owo, Ondo state. \\ Nigeria. \\ Email: opeadewumi@yahoo.com
}

\begin{abstract}
Diseases are not alien to human society. Corona virus disease 2019 is highly dreaded due to its high infectious capacity and its worldwide coverage. It violates geographical boundaries to attack people of all colours, races and ages, which represent the human resource of the organisations and countries. When the health of the employees is compromised, the productive activities within an organisation and nation will suffer. Using secondary source of data, it was discovered that there is high reduction in the quantity of goods and services produced on the part of the organisations, thereby resulting in low mobility of labour, low recruitment, poor human resource planning, reduction in wages and salaries, frustration of employment contracts and layoffs. It is recommended that government should create a post covid-19 enabling environment where businesses can thrive, organisations should provide the health and safety equipment to employees at workplace, employees should adhere to all safety measures in order to curb the pandemic and use the lockdown to improve their skills and competences by taking advantage of the online programmes that are related to their job performance.
\end{abstract}

Keywords: Human Resource, Corona Virus Disease, Health, Organisation, Nigeria.

\section{Introduction}

A current concern to the global community is that which affect the health and wealth of nations. Coronavirus disease (COVID-19) is an infectious disease caused by a newly discovered coronavirus. Coronavirus is one of the major pathogens that affects majorly the human respiratory system. Earlier outbreaks of coronaviruses (CoVs) include the severe acute respiratory syndrome (SARS)-CoV and the Middle East respiratory syndrome (MERS)-CoV which have been earlier described as a great public health threat (Hussin and Siddappa, 2020).

Most people infected with the COVID-19 virus will experience mild to moderate respiratory illness and recover without requiring special treatment. Older people, and those with underlying medical problems like cardiovascular disease, diabetes, chronic respiratory disease, and cancer are more likely to develop serious illness (https://www.who.int/healthtopics/coronavirus\#tab=tab_1). 
Pandemic disease is not alien to human existence. Human resource of the organisation is been threatened as it is part of the target of the virus attack. The corona virus disease, 2019 (covid19) which was first discovered in Wuhan, China is spreading like wild harmattan fire across the nations of the world (Said, 2020). In Nigeria, first case was confirmed on in Lagos on the $27^{\text {th }}$ of February 2020, since then the spread of covid-19 is on the increase, as at $7^{\text {th }}$ of June, 2020 total confirmed cases recorded in the country is 12,486. 3959 cases have been discharged and 354 deaths have been recorded in 35 states and the Federal Capital Territory having carried out 76,802 tests (https: nairametrics.com/2020/06/08/covid-19-update-innigeria).

Employees are not immune to all sicknesses and diseases. Corona virus disease 2019 (Covid19 ) is highly dreaded for its contagious nature, irrespective of age, race, gender or colour. The degree of its spread is increased with large gathering of people. This makes people within the organisation vulnerable to the disease, as such it is of concern to employees and employers alike. Health and safety of workers will lead to increase productivity, higher quality of work, increased workforce morale, reduced employee turnover and overall quality of life (Ahmad, Saltar and Nawaz, 2016). Whatever affects the health of the employees will affect the productive capacity of the organisation. Since organisations exist to produce need satisfying goods and services, whenever the ability of the organisation to produce goods and services is been threatened, the continuous existence of such an organisation is affected.

\section{Statement of the Problem}

Coronavirus Disease 2019 (COVID-19) has become a major health challenge leading to severe respiratory illness in humans (Hayat, et. al., 2020). In today's competitive business environment, human resource is the most valuable resource that an organisation is endowed with, as the shortage or surplus of it will affect the achievement of the objective for which organisations are set up. Organisations achieve the objectives for which it is set up when the human resource within the organisation put other organisation resources (such as, land, capital) into productive use. In the current global work environment, the cost of hiring, maintaining and retaining the human resource within an organisation is so huge that losing them to disease is a huge drain on the financial resources of the organisation. The enormous cost of a sick or diseased employee on the organisation cannot be over-emphasised. The disease can render the human resource of the organisation incapacitated and unable to discharge their duties as and when due and may ultimately result in death which will make the organisation to begin to source for a replacement which is at a cost.

The lockdown occasioned by the covid-19 pandemic has prevented the human resource from discharging their duties to the organisation. This will result in low productivity thereby forcing most organisation to cut cost through reduction in salary, low recruitment, inadequate human resource planning, and eventually lay-offs if the pandemic disease is not curtailed on time as folding up of some organisation is imminent.

\section{Objective of the Study}

The objectives of this study are to;

- discuss what corona virus disease 19 is all about

- ascertain the implication of covid-19 pandemic on human resource management and

- make recommendations on curbing the diseases 


\section{Significance of the Study}

The findings of this study will help government to protect the citizens and also assist the organization to protect their employees thereby protecting their investment.

\section{Limitation of the Study}

The lockdown prevented the researcher from reaching employees and management of organizations thereby making it impossible to use primary data.

\section{Literature Review \\ Conceptual Review \\ Covid-19}

Coronaviruses are a family of viruses that can cause illnesses such as the common cold, severe acute respiratory syndrome (SARS) and Middle East respiratory syndrome (MERS). In 2019, a new coronavirus was identified as the cause of a disease outbreak that originated in China. The virus is now known as the severe acute respiratory syndrome coronavirus 2 (SARS-CoV2). The disease it causes is called coronavirus disease 2019 (COVID-19) (Mayoclinic, 2020). Coronavirus disease 2019 (COVID-19) is defined as illness caused by a novel coronavirus now called severe acute respiratory syndrome coronavirus 2 (SARS-CoV-2; formerly called 2019nCoV), which was first identified amid an outbreak of respiratory illness cases in Wuhan City, Hubei Province, China. It was initially reported to the WHO on December 31, 2019. On January 30, 2020, the WHO declared the COVID-19 outbreak a global health emergency. On March 11, 2020, the WHO declared COVID-19 a global pandemic, its first such designation since declaring H1N1 influenza a pandemic in 2009 (David, 2020).

Coronavirus disease (COVID-19) is an infectious disease caused by a newly discovered coronavirus. Most people infected with the COVID-19 virus will experience mild to moderate respiratory illness and recover without requiring special treatment. Older people, and those with underlying medical problems like cardiovascular disease, diabetes, chronic respiratory disease, and cancer are more likely to develop serious illness.

The COVID-19 virus spreads primarily through droplets of saliva or discharge from the nose when an infected person coughs or sneezes, so it's important that you also practice respiratory etiquette (for example, by coughing into a flexed elbow).

The best way to prevent and slow down transmission is be well informed about the COVID19 virus, the disease it causes and how it spreads. Protect yourself and others from infection by washing your hands or using an alcohol-based rub frequently and not touching your face. At this time, there are no specific vaccines or treatments for COVID-19. However, there are many ongoing clinical trials evaluating potential treatments. (WHO, 2020) (https://www.who.int/health-topics/coronavirus\#tab=tab_1) .

The 2019 novel coronavirus disease (COVID-19) is a new strain of coronavirus that has not been previously identified in humans. It was first detected on the $7^{\text {th }}$ of January, 2020 in Wuhan, China.

"COVID-19 is caused by a virus that spreads through droplets released when an infected person coughs or sneezes. A person can become infected with this new coronavirus by being in close contact (within 2 metres) with a person infected with COVID-19. Infection can also spread by touching a surface that an infected person coughed or sneezed on. The first COVID19 case in Nigeria was confirmed on 27th February, 2020 in Lagos (Nigeria Centre for disease Control. 
Symptoms of COVID-19 are cough, shortness of breath, difficulty in breathing, fever, and muscle pain within 14 days of exposure to someone infected with the virus or returning from a country with ongoing community transmission" (NCDC, 2020).

Signs and symptoms of coronavirus disease 2019 (COVID-19) may appear two to 14 days after exposure. This time after exposure and before having symptoms is called the incubation period. Common signs and symptoms can include: fever, cough, tiredness, others are; shortness of breath or difficulty breathing, muscle aches, chills, sore throat, loss of taste or smell, headache, chest pain.

This list is not all inclusive. Other less common symptoms have been reported, such as rash, nausea, vomiting and diarrhea. Children have similar symptoms to adults and generally have mild illness. The severity of COVID-19 symptoms can range from very mild to severe. Some people may have only a few symptoms, and some people may have no symptoms at all. People who are older or who have existing chronic medical conditions, such as heart disease, lung disease, diabetes, severe obesity, chronic kidney or liver disease, or who have compromised immune systems may be at higher risk of serious illness. This is similar to what is seen with other respiratory illnesses, such as influenza.

Some people may experience worsened symptoms, such as worsened shortness of breath and pneumonia, about a week after symptoms start (Mayoclinic, 2020).

The virus appears to spread easily among people, and more continues to be discovered over time about how it spreads. Data has shown that it spreads from person to person among those in close contact (within about 6 feet, or 2 meters). The virus spreads by respiratory droplets released when someone with the virus coughs, sneezes or talks. These droplets can be inhaled or land in the mouth or nose of a person nearby. It can also spread if a person touches a surface with the virus on it and then touches his or her mouth, nose or eyes, although this isn't considered to be a main way it spreads.

The risk factors for COVID-19 appear to include:

- Recent travel from or residence in an area with ongoing community spread of COVID19 as determined by CDC or WHO

- Close contact (within 6 feet, or 2 meters) with someone who has COVID-19 for more than 5 minutes or being coughed or sneezed on by an infected person.

Although most people with COVID-19 have mild to moderate symptoms, the disease can cause severe medical complications and lead to death in some people. Older adults or people with existing chronic medical conditions are at greater risk of becoming seriously ill with COVID-19.

Complications can include:

- Pneumonia and trouble breathing

- Organ failure in several organs

- Heart problems

- A severe lung condition that causes a low amount of oxygen to go through your bloodstream to your organs (acute respiratory distress syndrome)

- Blood clots

- Acute kidney injury

- Additional viral and bacterial infections. (Mayoclinic, 2020)

\section{Protecting yourself and others from the spread COVID-19}

You can reduce your chances of being infected or spreading COVID-19 by taking some simple precautions: 
- Regularly and thoroughly clean your hands with an alcohol-based hand rub or wash them with soap and water. Why? Washing your hands with soap and water or using alcohol-based hand rub kills viruses that may be on your hands.

- Maintain at least 1 metre (3 feet) distance between yourself and others. Why? When someone coughs, sneezes, or speaks they spray small liquid droplets from their nose or mouth which may contain virus. If you are too close, you can breathe in the droplets, including the COVID-19 virus if the person has the disease.

- Avoid going to crowded places. Why? Where people come together in crowds, you are more likely to come into close contact with someone that has COIVD-19 and it is more difficult to maintain physical distance of 1 metre (3 feet).

- Avoid touching eyes, nose and mouth. Why? Hands touch many surfaces and can pick up viruses. Once contaminated, hands can transfer the virus to your eyes, nose or mouth. From there, the virus can enter your body and infect you.

- Make sure you, and the people around you, follow good respiratory hygiene. This means covering your mouth and nose with your bent elbow or tissue when you cough or sneeze. Then dispose of the used tissue immediately and wash your hands. Why? Droplets spread virus. By following good respiratory hygiene, you protect the people around you from viruses such as cold, flu and COVID-19.

- Stay home and self-isolate even with minor symptoms such as cough, headache, mild fever, until you recover. Have someone bring you supplies. If you need to leave your house, wear a mask to avoid infecting others. Why? Avoiding contact with others will protect them from possible COVID-19 and other viruses.

- If you have a fever, cough and difficulty breathing, seek medical attention, but call by telephone in advance if possible and follow the directions of your local health authority. Why? National and local authorities will have the most up to date information on the situation in your area. Calling in advance will allow your health care provider to quickly direct you to the right health facility. This will also protect you and help prevent spread of viruses and other infections.

- Keep up to date on the latest information from trusted sources, such as WHO or your local and national health authorities. Why? Local and national authorities are best placed to advise on what people in your area should be doing to protect themselves (W.H.O, 2020).

(https://www.who.int/emergencies/diseases/novel-coronavirus-2019/advice-forpublic)

\section{Advice on the Safe use of Alcohol-Based Hand Sanitizers}

To protect yourself and others against COVID-19, clean your hands frequently and thoroughly. Use alcohol-based hand sanitizer or wash your hands with soap and water. If you use an alcohol-based hand sanitizer, make sure you use and store it carefully.

- Keep alcohol-based hand sanitizers out of children's reach. Teach them how to apply the sanitizer and monitor its use.

- Apply a coin-sized amount on your hands. There is no need to use a large amount of the product.

- Avoid touching your eyes, mouth and nose immediately after using an alcoholbased hand sanitizer, as it can cause irritation.

- Hand sanitizers recommended to protect against COVID-19 are alcohol-based and therefore can be flammable. Do not use before handling fire or cooking. 
- Under no circumstance, drink or let children swallow an alcohol-based hand sanitizer. It can be poisonous.

- Remember that washing your hands with soap and water is also effective against

COVID-19

(WHO,

2020).

(https://www.who.int/emergencies/diseases/novel-coronavirus-

2019/advice-for-public).

\section{Methodology}

The study basically relied on secondary data collected through different publications and archives such as the international agencies reports, news item, texts, journals, magazines, Newspapers, Bulletin and the internet.

Confirmed Corona Virus Cases in Nigeria on State basis as at $7^{\text {th }}$ of June, 2020.

\begin{tabular}{|c|c|c|}
\hline $\mathrm{S} / \mathrm{N}$ & STATE & $\begin{array}{l}\text { NUMBER OF } \\
\text { CONFIRMED CASES }\end{array}$ \\
\hline 1 & Lagos & 5767 \\
\hline 2 & Kano & 999 \\
\hline 3 & Abuja & 952 \\
\hline 4 & Edo & 401 \\
\hline 5 & Katsina & 395 \\
\hline 6 & Oyo & 365 \\
\hline 7 & Borno & 356 \\
\hline 8 & Ogun & 355 \\
\hline 9 & Kaduna & 343 \\
\hline 10 & Rivers & 332 \\
\hline 11 & Bauchi & 291 \\
\hline 12 & Jigawa & 283 \\
\hline 13 & Gombe & 217 \\
\hline 14 & Delta & 148 \\
\hline 15 & Kwara & 135 \\
\hline 16 & Sokoto & 129 \\
\hline 17 & Plateau & 115 \\
\hline 18 & Nasarawa & 112 \\
\hline 19 & Ebonyi & 103 \\
\hline 20 & Abia & 83 \\
\hline 21 & Zamfara & 76 \\
\hline 22 & Imo & 68 \\
\hline 23 & Yobe & 52 \\
\hline 24 & Osun & 49 \\
\hline 25 & Akwa Ibom & 45 \\
\hline 26 & Niger & 44 \\
\hline 27 & Adamawa & 42 \\
\hline 28 & Ondo & 42 \\
\hline 29 & Kebbi & 35 \\
\hline 30 & Bayelsa & 30 \\
\hline 31 & Enugu & 30 \\
\hline
\end{tabular}




\begin{tabular}{|l|l|l|}
\hline 32 & Anambra & 29 \\
\hline 33 & Ekiti & 29 \\
\hline 34 & Taraba & 18 \\
\hline 35 & Benue & 13 \\
\hline 36 & Kogi & 3 \\
\hline
\end{tabular}

Source: http://nairametrics.com/2020/06/08/covid-19-update-in-nigeria/ (retrieved on 8/6/2020).

\section{Human Resource Management}

Human resource is a valuable to organizations all over the globe. The health and wholeness of employees will determine to a large extent their individual and collective contribution to the productive activities in an organization. The need to give urgent attention to whatever will affect the supply of human resources in the right quantity and quality and at the right time and place. Covid pandemic, if not collectively compacted can truncated the existence of organizations, nations and the human society at large. $21^{\text {st }}$ century organisation that must remain in business in the face of the dwindling economic reality must ensure that its human resource is in the right quantity, quality and in good state of health so as to discharge their duties as expected of them by the organisation as meeting the customers need depends largely on this. The need to ascertain the human resource implication of covid-19 disease so as to guide against its detrimental effect on employees and organisations.

\section{Covid -19 and Human Resource Management Implication in Nigeria}

i. Poor Welfare of Frontline Officer: the health care professionals that constitute the frontline workers in the face of this dreaded corona virus are not given adequate and commensurate compensation expected and require for the level of sacrifice and risk associated with performance of their duties in the face of the pandemic. Government seems to be paying lips service to curbing the disease as the disease cannot be combated without adequate motivation of the doctors, nurses, medical laboratory practitioners and all stakeholders in the health sector, but government seem not bordered by their protection as occasioned by inadequate provision of personal protective equipment and provisions of necessary allowance due to the affected workers.

Life insurance which is a form welfare package for the frontline workers has been an issue of debate without recourse to the sensitivity of the duties of this health workers. This has led to incessant protest and strike actions by the concerned health workers associations.

ii. Compensation: Ensuring that all employees engaged are compensated equitably based on skills, job demands, grade, performance, organisations ability to pay is one of the major functions of human resource management. Some health workers have not been paid their salaries and entitlement for many months, while others are still having some allowances left unpaid. This is unfair treatment to those that are at the forefront of the fight against covid-19 pandemic. This will demotivate workers as the employers (mostly government) is unwilling to make good their own part of the employment contract. 
iii. Geographical mobility of labour: The number of foreign-born people in rich countries has consistently increased since 1960, and the emigration of high-skilled people from poor countries has escalated (Frédéric, 2014). But covid-19 era has witnessed mass exit of highly skilled foreign nationals from Nigeria. This is on the increase as some of them prefer to go over to their nation since the lockdown will not allow them to discharge their duties which is their primary aim of coming into the country. Labour mobility is hampered and discouraged with covid-19 lockdown.

iv. Human Resource Planning: getting the right human resource in the right quality, quantity and at the right time is the objective of human resource planning. Organisations make sure that they strike a balance between the human resource demand and human resource supply. This will prevent any loss due to shortage or surplus of supply as both has its implication on expenditure of the organisation on the human resource. A surplus implies an idle human resource, which the organization will pay for without any commensurate benefit derived from them by the organisation; a shortage will make the organisation unable to meet with human resource demand during peak period.

Covid -19 pandemic has prevented the organisation form being able to accurately predict the required human resource per time as business activities fluctuates as a result of the lockdown. Even the supply of services by the human resource on the organisations payroll cannot be guaranteed due to threat of the pandemic as some of them may be affected and may not be able to discharge their duties as and when due.

The human resource supply for some jobs that are professional in nature cannot be guaranteed due to the sensitivity of the period and shortage of supply. An example of these are health professionals. Some might have been affected by the disease while others may not be willing to work as the risk is higher than the hazard allowance paid to them.

v. Training and development: this entail the acquisition of skills and knowledge needed for performance of task. It is a continuous process within the organization as new entrants needed to be trained on the rudiments of their jobs and old employees needs training for them to be more efficient on their jobs. Covid-19 has ushered in an era that will require most employees to work from home. Which will require the employees to acquire relevant knowledge of information and communication technology as it affects their jobs.

vi. Recruitment: most organisation will employ technology in some of their routine activities such as artificial intelligence which allows machine to perform some human resource duties. This will eventually reduce the rate of recruitment into the affected activities.

vii. Layoffs: some organisations during covid-19 period are working online. This organisations start and complete all their transactions with their clients online. This will lead to contraction in organisation activities and consequently result in merging of roles performed by different employees into one single role performed 
by an individual. Thereby reducing the human resource required by the organisation. Employees whose roles falls within the merged ones may be rendered redundant. Other organisations may layoff due to inability to engage in business activities due to the effect of the lockdown.

viii. Loss of remuneration: Employees come to the organisation to offer their services to the organisation at a cost, which is the remuneration received for job performance. Organisations that have no strong financial base may find it difficult to meet its financial obligations to its human resource during and after covid-19 lockdown period which is occasioned by loss of productive activities. Most small and medium scale organisations have not recover form the last recession in the country. Some are having many months' salary that are unpaid before the covid19 lockdown. This may remain unpaid and payment for the lockdown period may not be paid at all, as the ones that involve actual work performance are yet to be paid. Some may pay lesser than expectation, while others may decline payment outrightly as there is weak enforcement of labour laws within the country on this.

ix. Working from home: some employees in Nigeria would have enjoyed running a virtual office but epileptic power supply has hampered their intention in the face of covid-19 lockdown. As most work that can be done from home have been halted due to electricity challenges and the cost of getting an alternative power supply is high and unaffordable since this additional cost has not been foreseen and budgeted for.

x. Frustration of Employment Contract: Most Employment contract that are strictly for specific period of time have been frustrated and the parties to the contract can no longer make good their agreement. This will hamper productivity of the affected organization.

\section{Government Effort So Far}

On the $23^{\text {rd }}$ March, 2020, the Federal Government issued directives for the cancellation of large gathering, places of worship, social and sporting events for an initial period of 14 days as a measure to reduce the spread of the disease. This also includes closure of non-essential businesses. (NCDC,2020).

Federal government in a bid to curtail the spread of the pandemic disease, has directed that all movement should seize in FCT, Lagos and Ogun that have recorded rapid increase in cases of covid-19 for an initial period of 14 days, effective from 11pm on Monday, 30 $3{ }^{\text {th }}$ March, 2020. The cessation of movement which was extended by another two-weeks period, has been partially put on hold with the commencement of the operation of some businesses from May 4 , which was preceded by declaration of overnight curfew from 8pm to 6am throughout the country effective from April $27^{\text {th }}, 2020$. This is accompanied by the phased and gradual easing of the lockdown measures in FCT, Lagos and Ogun states, with effect form Saturday, $2^{\text {nd }}$ may 2020 at 9am. The different state government also imposed some form of lockdown or curfew at one period or the other with various regulations on social gatherings and health protocols. The federal government has also directed the establishment of isolation centres in all the states of the federation including the FCT. The government has made frantic efforts at 
curtailing the disease but the slow pace at which people can be tested and receive result of such test is increasing the spread of the disease.

\section{Theoretical Review The Tannahill Model}

Andrew Tannahill created the health promotion model in the 1980s. it encompasses three interdependent spheres of activity namely: health education, disease prevention and health protection. Health education deals with how knowledge, beliefs, attitudes and behaviour of the people can be altered in such a way that will enhance their health. Disease prevention attempts to reduce the risk vulnerability and impact of the disease. Health protection entails legal controls, policies and voluntary codes of practice intended to hinder ill health and improve well-being.

This approach is appropriate for this study as there is need for the government and all stakeholders in health sector to adequately equip the people with necessary information concerning the cause, symptoms and its effect on the individual, communities and the nation at large. The disease prevention will enable the people to know all that is needed to avoid being infected by the diseases, while health protection will enable the government to put in place laws and policies that will ensure compliance to all the safety protocols.

\section{Conclusion}

Countries of the world rely on production activities for sustenance and development. Production of goods and services is made possible by the human resources they are endowed with. When there is an attack on the health of human resource within a nation, breakdown in productive activities is inevitable. The need to take personal and collective responsibility at curtailing the spread of the pandemic and outrightly stern the tide of the storm of covid-19.

\section{Contribution of this Research to Knowledge}

This work will furnish government at all levels, organizations and employees with the information on the effect of covid-19 on the human resource management in Nigeria and how it can be managed such that it does not affect the production of goods and services within the organisation and the nation at large since this hinge on the health of the human resource.

\section{Recommendations}

Covid-19 is ravaging the health and wealth of the human resource globally, as Covid-19 poses a threat to all individual employees, organisations, nation and all countries of the world, it should be seen a public health emergency that requires the contribution of all humans to ensure it is curtailed. This can be achieved through the following;

\section{Employers Should}

put in place all health and safety measures to guide against the spread of the diseases among the employees at workplace the during and after the lockdown; invest in technologies that can keep production activities going during lockdowns, regardless of its duration; compensate professionals in health sector equitably, so that the quest for overseas job will be unattractive and unappealing to them. 


\section{Employees Should}

use the lockdown to improve their skills and competences by taking advantage of the online programmes that are related to their job performance; maintain proper hygiene and social distance during and post covid-19 lockdown.

\section{Government Should}

create a post covid-19 enabling environment where businesses can thrive. This include but not limited to distribution of relief materials, loans and grants, subsidies on some materials used by organisations for production so as to guide against laying-off of employees by organisation due to paucity of fund that may result due to temporary shutdown during covid19 lockdown.

\section{Reference}

Ahmad, I., Saltar, A., \& Nawaz, A. ( 2016). Occupational Health and safety in Industries in Developing World. Gomal Journal of Medical Sciences. 14(4). Pp. 223 - 228.

David, J. C. (2020). Coronavirus Disease 2019 (COVID-19). https://emedicine.medscape.com/article/2500114-overview Retrieved on $16 / 6 / 2020$

Frédéric, D. (2014). The Brain Drain from Developing Countries. IZA World of Labor 2014: 31 Hayat, O., Loubna, K., Mohamed, B., Nour, E. D., Hamada, I., Noureddine, B., Amine, E., and Mohamed, B. (2020). The Pathogenesis of Coronavirus Disease 2019 (COVID-19): Evaluation and Prevention. Journal of Immunology Research. (New Insights into Immune-based Diagnosis, Therapy and Prophylaxis for Infectious Diseases 2020):7

Hussin, A. R., Siddappa, N. B. (2020). The epidemiology and pathogenesis of coronavirus disease (COVID-19) outbreak. Available from: https://www.researchgate.net/publication/339515532_The_epidemiology_and_pat hogenesis_of_coronavirus_disease_COVID-19_outbreak [accessed Feb 04 2021].

Mayo Clinic (2020). Corona Virus. https://www.mayoclinic.org/diseases-conditions/coronavirus/symptoms-causes/syc20479963 Retrieved on 16/6/2020

NCDC. (2020). Covid-19 Guidance for Schools in Nigeria. https://ncdc.gov.ng/themes/common/docs/protocols/175_1583410399.pdf. Retrieved 4/3/2020.

Said, N. (2020). Coronavirus Covid-19. Journal of Ongoing Chemical Research 5(1), $7-13$. Tannahill, A. (2009). Health Promotion: The Tannahill Model Revisited. Public Health, 123(5), 396-399.

W.H.O. (2020). Coronavirus disease (COVID-19) advice for the public (https://www.who.int/emergencies/diseases/novel-coronavirus-2019/advice-forpublic). Retrieved on $16 / 6 / 2020$

W.H.O. (2020). Corona Virus. (https://www.who.int/health-topics/coronavirus\#tab=tab_1) . Retrieved on 16/6/2020.

Nairametrics.com (2020). Covid-19 Update in Nigeria.

http://nairametrics.com/2020/06/08/covid-19-update-in-nigeria/ Retrieved on 8/6/2020. 